\title{
Popper as a process: revisiting the appropriation of the Popperian philosophy by the cladists during the "systematics wars"
}

\author{
Marcelo Domingos de Santis ${ }^{1}$ \\ 1 Universidade de São Paulo (USP), Instituto de Biociências (IB-USP), Departamento de Zoologia. São Paulo, SP, Brasil. \\ ORCID: http://orcid.org/0000-0003-4949-6433. E-mail:mrclsantis@gmail.com
}

\begin{abstract}
The philosophy of Karl Popper was strongly used by the cladists in their battle against evolutionary and numerical taxonomy. It became known as "Systematics Wars" by David Hull. His historical account in Science as a Process, described the outcome of that era that end up with the victory of cladistics. Claiming it as hypothetico-deductivist, and falsificationist, cladists have transformed and distorted Popper, that almost nothing of these ideas survived scrutiny. One of the Hull's conclusion was that the success of cladistics was largely due to their ability to maintain social cohesion and intellectual orthodoxy during the years of the Systematic Wars. In this paper, I will provide a concise historical development about the appropriation of Popper's ideas that were used by systematics, both as a defense and as a critic, trying to make clear the interpretations of these authors in relation to Popper and their research program. Using David Hull's General Theory of Selection Processes, I will argue that these facts were, partially, to a heavy adherence to Popper's philosophy.
\end{abstract}

Key-Words. David Hull; Cladistics; Parsimony; Philosophy of Science; Phylogenetic Systematics.

\section{INTRODUCTION}

The importance David Hull (1935-2010) has to the Philosophy of Biology is huge. He is cited as "the person most responsible for the philosophy of biology achieving the status within philosophy that it has today. He is the single figure most responsible for its flourishing. (Godfrey-Smith, 2010, p. 749)".

Furthermore, his importance for the development and maturation to the philosophy of cladists is also very representative. This can be exemplified by giving two, rather different in approaches, citations, "David Hull (in lit., 12/22/02) recounts how early in the 'cladistic revolution', Gary Nelson and Norman Platnick from the American Museum of Natural History asked him to suggest a self-contained book on the philosophy of science. His suggestion was Popper. Rieppel (2008b, p. 297); David Hull, perhaps the first to identify the bully-boy tactics in systematics... (Williams \& Ebach, 2013, p. 178)".

Hull's influence in the systematic literature is very relevant and substantial. The straight- forward confirmation of this affirmation are the various citations of cladists (and non-cladists) of his articles, e.g., his "Contemporary Systematic Philosophies" (Hull, 1970), and by indirect ways by their acknowledgments, where Hull was frequently cited; as an example, Hull was acknowledged by Platnick \& Gaffney (1978b, p. 387) for "his painstaking criticisms of drafts of this series of reviews" that he performed in his role as associate editor of Systematic Zoology (from 1975-1982), the principal journal that the "systematics wars" took place. These "systematics wars", that occurred between the mid-1960s through the 1980s, was characterized by a series of explosive debates between competing theories of biological classification and phylogenetic inference. These competing theories were the (1) phylogenetic systematics ${ }^{1}$, the (2) evolutionary taxonomy and (3) the numerical taxonomy. The detailed history of these conflicts exist: David Hull's book Science as a Process: An Evolutionary Account of the Social and Conceptual Development of Science (Hull, 1988) provides a vividly and detailed description of these times, mainly because he directly partici-

\footnotetext{
1 In the literature, we can observe that the name "cladist" appears replacing "phylogenetic systematics" derives from Mayr (1965). He used cladistics to refer to the persistence of this research group in merely reconstructing the "branching pattern". He believed it was misleading that cladists call themselves a phylogenetic school, for they would ignore much of the phylogenetic process, e.g., ignoring differences in evolutionary rates (grades). This terminology, even if initially despised by the cladists (Hull, 1988), was adopted by the systematists, and will, therefore, be used interchangeably herein.
} 
pated in those debates. Hull had a unique vantage point for analyzing this historical case. Trained as a philosopher and historian of science, Hull was so closely involved with his study of systematists that he became, besides an associate editor of Systematic Zoology, a board member of the Society of Systematic Biology (formerly known as Society of Systematic Zoology).

After de 1970s, as one of the results of the "systematics wars", the cladists quickly gained the general acceptance of the scientific community, leaving the program of numerical taxonomy and Evolutionary systematatics in ostracism. At the end of the 1980s, cladistic analysis were quite common in the systematic literature. In the 1990s (to nowadays), almost all publications dealing with systematics are based on cladistic analysis. As David Hull (1988) said, the cladists won the "war of systematics".

While the method of cladistic analysis rapidly accelerated and ended up translating into easy-to-use computer software packages, the underlying theory and philosophy of Hennig's $(1950,1966)$ phylogenetic systematics remained unexplored. Instead, especially in the last four decades, the philosophy of science elaborated by Karl Popper (2002) was appealed to support and defend the cladists. Unequivocally, no other work of a philosopher had so much influence during this formative period in systematics. Much, but not all, of the early discourse on Popper and systematics dealt with the philosophical basis of systematics as science. Starting from Wiley (1975), Popper was always referred to as his patron saint (Hull, 1988), to the present day, e.g., Kluge (2009); Farris (2013); Crother \& Murray (2015); Brower (2016).

This analysis is not about whether Popper's philosophy of science is good, adequate, accurate or practical, but instead will address what Popper wrote and whether his philosophy applies to phylogenetic systematics, and trace the motives of their longevity influence within this research program. Starting with the evidence of the main articles that both defended and criticized Popper's ideas in systematic, I will examine what was the role of Popper regarding this "victory". By using David Hull's thesis, the so-called General Theory of Selection Processes (Losee, 2001), which is a thesis explaining the conceptual change in the social organization of science based from three contrasting key elements: (1) desire for credit in opposite to mutual verification; (2) competition in opposite to cooperation and (3) cohesion in opposite to social isolation, as a factor of success among cladists. Therefore, according to Hull, the success of cladistics was largely due to cladists ability to maintain social cohesion and intellectual orthodoxy during the early years of the dispute in contrast to the more loosely organized pheneticists; herein I will argue for the importance that Popper had for this process.

\section{Hull's thesis}

Broadly speaking, Hull's thesis says that conceptual change occurs most rapidly in areas of science, where scientists are organized into tightly knit research groups.
Traditionally, the philosophers of science have argued that the growth of knowledge occurs through continuous testing and the selective elimination of hypotheses. Hull agrees, but emphasizes that this screening process is neither a random nor an individual subject; is a social phenomenon. So, by emphasizing the social structure of science, Hull developed a naturalistic philosophy. For instance for this social approach, a scientist rarely submits his estimation hypothesis to rigorous scrutiny. Scrutiny of hypotheses is usually made by other scientists, usually by their intellectual opponents. Consequently, Hull argues that conceptual development occurs most rapidly in the areas of science, divided into competing research groups.

In both its competitive and cooperative aspects, science is a social phenomenon that occurs mainly at the level of the research group. One of the most interesting implications, and for Hull most important, of this analysis of conceptual change is that concepts should be thought of as lineages, not types. As concepts are transmitted from one scientist to another, they are often modified. Within a conceptual lineage, ideas can, in fact, become so modified that they do not resemble the original. Other important set of ideas developed in Science as a Process comprise a version of evolutionary epistemology, that is, plainly: a naturalistic approach to epistemology, which emphasizes the importance of natural selection in two primary roles. In the first role, selection is the generator and maintainer of the reliability of our senses and cognitive mechanisms, as well as the "fit" between those mechanisms and the world. In the second role, trial and error learning and the evolution of scientific theories are construed as selection processes (Bradie \& Harms, 2017).

Hull applied his replicator/interactor analysis of evolution to change within science itself. Selection, being a process in which the differential extinction and proliferation of interactors cause the differential perpetuation of the relevant replicators (Hull, 1988). Replicators and interactors being the entities that function in selection processes, and scientific ideas are competing replicators in something like the way genes are. In conceptual lineages, we have the replicators and the interactors. Replicators do not interact with the environment; it is the scientists who interact with the environment, scientific concepts not. But, this approach has not been especially fruitful (Godfrey-Smith, 2010), and it has been criticized by some authors (Dupré, 1990; Kitcher, 1988; Sterelny, 1994). Therefore, I will not give much emphasis in this method herein; the analogy can be interesting, but we do not need to use it as a base to this (or any other) theory of science. Finally, the epistemic tools scientists have developed for evolutionary theory - things like quantitative models, type specimens, comparative methods, and so on - fail to carry over to social processes (Sterner \& Lidgard, 2018).

Therefore, Hull applied the General Theory of Selection Processes in two ways-as a framework for the interpretation of the history of science, and as a theory of science. One of its consequences, it would be evolutionarily self-defeating to fabricate data or otherwise un- 
dermine the scientific enterprise. Hull's theory explains why cases of professional misconduct are rare among scientists, and provides a rationale for the success of science as a point in the interpretative framework for the delineation of conceptual lineages (Losee, 2001).

\section{Popper's Philosophy and its relation to Biology}

Karl Popper (1902-1994) is considered one of the most influential philosophers of twentieth-century science. He is perhaps best known for his criterion of demarcation between science and pseudoscience. Popper was determined to identify some criterion for distinguishing scientific theories from pseudo-scientific theories. This criterion was for Popper the mark of a scientific theory. According to Popper, a theory is scientific only if it makes predictions that can be tested and possibly shown to be false, i.e., it is falsifiable (Sarkar \& Pfeifer, 2006). Briefly, falsificationism is a philosophical thesis about the scientific method. In Popper's view, scientific theories and hypotheses should not be evaluated on the basis of confirmation (or verification), but of falsification (Popper, 1959).

The philosopher Karl Popper is still enormously popular with natural scientists in general and biologists in particular, even though in recent discussion in academic philosophy of science, he definitely seems to be fading (Godfrey-Smith, 2007). As an example of his popularity we can read the following statement from the cladists: "we agree with Medawar's characterization of Popper as 'incomparably the greatest philosopher of science that has ever been'... and we urge every systematist to acquire some knowledge of his work. Platnick \& Gaffney (1978b, p. 360)".

Still within the cladists, in 1979 he was awarded the Gold Medal by the American Museum of Natural History for "Distinguished Service to Science" (American Museum of Natural History, 1979). However, as noted above, numerous philosophers has argued against such claim. For instance, Stamos (2007) affirmed "... that biologists should stop citing Popper on what a genuine scientific theory is, or on what good science is." And argued that as biology has no laws (same position supported by some philosophers, e.g., Beatty (1995), and for Popper genuine science is only through the use of laws of nature; no testing of laws, or no use of laws for explanation or prediction, and no science. Biology, more precisely, evolutionary biology, then, would not be his "science". However, even with no genuine laws of its own, Biology would still count as a science, only now as a historical science (for details, see Cleland, 2002).

Popper also wrote about evolutionary theory (1972, $1974,1978)$. However, he had some problems with this subject that are well known (Hull, 1999; Elgin \& Sober, 2017). Popper (1957) argued that there are no general laws governing the evolution of societies, the evolution of organisms, or the evolution of the whole universe. What we have for these evolutions are trends. For Popper trends are not laws, and about this, he stated, "a statement asserting the existence of a trend at a certain time and place would be a singular historical statement, not a universal law. (Popper, 1957, p. 115)".

With accusations of evolutionary theory being: "tautological, or almost tautological" (Popper, 1972) and "I have come to the conclusion that Darwinism is not a testable scientific theory, but a metaphysical research programme... (Popper, 1974, p. 134)".

Later, Popper (1978) changed his mind and denied that Darwinism is a tautology, and that natural selection, though difficult to test, is in principle testable. These statements were one of the reasons why the biologists' failed to take his views seriously (Hull, 1999). He tried to improve his ideas, e.g., Popper (1978), but Hull (1999) have not been able to find any biologist who has taken up Popper's suggestion, and I think this is true even today.

\section{POPPER ADEQUACY WITH PHYLOGENETIC SYSTEMATICS}

\section{Main critics and defenders of Popper's view}

Before the 1970s, Popper's work did not directly affect systematic thinking and its methodology ${ }^{2}$. His appearance in systematics appeared when Bock (1973) introduced it to systematists, drawing attention to philosophy in the sciences of classification "Biological classification is a science, and as such should be treated within some philosophical framework of the criteria of scientific theories and methodologies. Herein, I accept the philosophical approach to science advocated by Karl Popper... And I would advocate that the theory and particularly the methodology of biological classification should be formulated according to the Popperian philosophy of science. (Bock, 1973, p. 381)".

Bock argued that classical evolutionary classification should prevail as a classification system on numerical taxonomists and cladistics because of its consistency with Popper's ideas "Classical evolutionary classification is based on the Popperian philosophy of scientific demarcation and methodology and on the modern synthesis of Darwinian evolution... (Bock, 1973: 391)".

Quickly, the cladists recruited Popper as demonstrating that the phylogenetic systematics, unlike its competitors, that was applicable to Popper, and so would be the only genuine science for ranking the phylogenetic order. In this way, appropriating Popper's philosophy. This is explained by Hull (1988) as being the resurrection of a famous but long-neglected scientist or philosopher in the area of disputed research, scientists feel a genuine obligation to recognize unappreciated work. These references are used to promote the contributions of the author himself and his research group. If a scientist thinks his visions are being ignored or treated unfairly, it is difficult for him to say this without seeming selfish, so unrecognized famous precursors are especially useful under

2 Ghiselin (1966) made the first implicitly reference to Popper, but was far from basing all the structure of taxonomic theory and providing a background for an objective choice among competing systematic methodologies, as Bock (1973) made for the evolutionary taxonomy. 
such circumstances. In the individualization of programs in the scientific approach, if opponents choose a specific figure as a patron saint, one can always try to co-opt their choice. Just like the cladists have done with Popper.

The first cladist to do this was Wiley (1975). As a response to Bock (1973), the author stated that, in fact, only phylogenetic systematics would be in accordance with Popper's principles (Wiley, 1975). Popper constitutes the first pillar of phylogenetic systematics in its "war" with the evolutionary and pheneticist. However, Hull (1988) states that this author starts from important ways of the views expressed by Popper himself. Wiley and the systematists did not simply adopt Popper's views; they transformed them. This can be demonstrated in this same article "an hypothesis of synapomorphy which has a greater number of potential falsifiers may be said to exist at a higher level of universality than another hypothesis of synapomorphy which has fewer potential falsifiers and the former would have more weight than the latter when they conflict [italics in the original]. (Wiley, 1975, p. 236)".

It should be noted that in principle, following Popper's philosophy, neither the justifications of Bock (1973) nor of Wiley (1975) fit Popper (the justifications for this statement will follow herein). Popper's transformation continued, as in Platnick \& Gaffney (1977), which is part of a series of revisions by Platnick \& Gaffney (1977, 1978a, $1978 b)$ with the purpose of "informing systematists about relevant ideas in Popper's works" (Gaffney, 1979, p. 105). In this work, Platnick \& Gaffney (1977) emphasized in the systematic literature the use of universal statements in their research program to fit Popper's philosophy "within the context of phylogenetic systematics... The term 'vertebrate' [as a universal law of nature] can be used to refer to any organism that possesses the defining characters (synapomorphies) of both Vertebrata and all the larger groups to which Vertebrata belongs. (Platnick \& Gaffney, 1977, p. 140)".

As can be seen, these authors went so far as to reject what Popper (1957, p. 107) himself said about the case of "vertebrates having a pair of common ancestors" as being universal. About this issue, Popper wrote that "the evolution of life on earth... is a unique historical process... Its description, however, is not a law, but only a singular historical statement. (Popper, 1957, p. 108)".

As we put Popper's terminology into scrutiny, it is possible to state that we can be deceived as his terminology can be misleading (Hull, 1999). About this series of article by Platnick \& Gaffney, Rieppel (2008a) stated that they really had made a misconception that the hypothetico-deductive model of scientific explanation in their application to cladistics. Thus, these cladists have "used and abused philosophers" as they choose Popper as a weapon against their opponents, at the same time failing to understanding his philosophy (Hull, 1981). Clearly, 'All spiders in the New World have eight legs', cannot be argued using Popper's philosophy since universal statements stem from the assumption that they are unrestricted in the temporal and spatial realm. Moreover, scientific laws are strictly unverifiable. All these theories are of a universal nature, and no finite collection of ob- servation statements, however large, is logically equivalent, or can justify, an unrestricted universal proposition. Then by canonical modus tollens based on the rule of classical logic, it is possible to infer deductively the falsity of a universal proposition, once established the truth-value of an appropriately related singular proposition. For Popper this means that the central type of inferences involved in science is deduced from observation statements of the form "This A is not X" for the falsity of the corresponding universal hypotheses, and such inferences occur in the critical tests of such hypotheses, and not in its generation.

Although Popper is right that a universal generalization can be distorted by only a negative instance, many statements in science are not that way. For example, scientific theories claim the existence of things like black holes, atoms, viruses, DNA, and so on. Statements that affirm the existence of something cannot be falsified by the inability to find them (Ladyman, 2002). The existential statements of biology are exactly of this kind, for they are space-temporally restricted (Stamos, 2007). As Hull (1988) argued, the rise of cladistic scientific research groups, based while they were centered on the American Museum of Natural History in New York, will be important for this function of social cohesion. Popper's articles were extensity used by this group, which was nominally referenced by the figure of Gareth Nelson by Hull (1988), alongside all other people directly or indirectly attached to him and to their original group, such as Edmund Wiley, Norman Platnick, James Farris, Daniel Brooks, Joel Cracaft, Collin Patterson, and Arnold Kluge (the details of affiliations and historical social cohesion among these people are offered by Hull (1988).

The first systematist to criticize the existence of these universal statements in phylogenetic systematics was Kitts (1977). He states that in constructing a phylogeny in which the descendant-ancestral relationship enters two populations, the asymmetry between verifiable and falsifiable is lost. This is why this relation is a statement about two universal classes and is therefore equivalent to a conjunction of statements about the relations between individuals. That statement would be, at least in principle, both verifiable and falsifiable. Moreover, the difficulty of verifying or falsifying it would be a contingent difficulty in the search for historical knowledge. Kitts (1977) continues his argument showing the incompatibility of universal statements in Systematics, and, in this way failing to be in accord to Popper's philosophy.

After Kitts, other systematics scientists countered the application of Popper's falsifiability in systematics, arguing over the inapplicability of universal statements, and the inadequacy of the hypothetical-deductive method. For example, Panchen (1982) stated that, "again (and again unfortunately) this would still not be a case of the hypothetico-deductive method according to Popper, despite the logical validity of modus tollens and the truth of the propositions. This is because each of those propositions is either contingent, i.e. not a strictly universal statement but one that described a spatio-temporally limited state of affairs... (Panchen, 1982, p. 312)". 
Then Hull (1983) himself wrote on this subject, explaining the differences between universal, numerical and singular (or existential) utterances. He argued that only the universals does the asymmetry between falsification and verification exist, and that systematics does not have this characteristic, thus, it does not fit Popper. Subsequently, he warns the systematists about their patron saint stating that: "All truth does not reside in the writings of Sir Karl Popper." (Hull 1983, p. 178). To resonate Popper's (1959) 'The Logic of Scientific Discovery' Gaffney (1979) wrote an influential article titled 'An Introduction to the Logic of Phylogeny' in which he sketched a hypothetico-deductive approach to the cladistic analysis (Rieppel, 2008a). This article was also, once again, an appeal against the so-called "authoritarianism", mainly by Mayr and Simpson, from the evolutionary taxonomy (Gaffney, 1979). The continued application of the hypothetico-deductive approach revealed to be very important for the cladists, as can be seen used by some very influential books, e.g., Wiley \& Lieberman (2011) and Ax (1987) and articles, e.g., Farris (1983) and Kluge (2005).

The cladists replies were strong and even aggressive against these propositions of universal statements. According to his thesis, to succeed in science the scientists must behave aggressively. Therefore, it follows that scientists are being asked to behave in ways they do not find especially easy. This could be clearly observed by the responses against Kitts (1977). His claim was immediately attacked in unambiguous terms by several cladists. For instance, in a series of replies, Cracraft (1978), Nelson (1978) and Patterson (1978) argued that existential statements are universal; this united front was a cohesive response to these attacks. But the strongest example of aggressiveness of the cladists against a person with opposing ideas is the revision of Hull's book Science as a Process by Farris \& Platnick (1989) where they say: "In short, Hull has produced a flawed (and sometimes despicable) book that systematists will peruse mostly for the "gossip" it contains". (Farris \& Platnick, 1989, p. 310).

This cladistics created a social circle based on and united by a particular thesis, namely, Popper's knows best, on which everything else - history, theory, methodology - is judged. Thus, these animosities that arise during the course of science are complicated by the alliances that scientists form. A common answer among scientists is to attack "opponents" while they mutually support allies (Hull, 1988).

\section{On the ad hoc hypotheses of homoplasy}

Another point of the appropriation of Popper's ideas in systematics was the idea that parsimonious genealogical hypotheses are those that minimize the requirements for ad hoc hypotheses of homoplasy. This statement had its first appearance in Gaffney (1979), but it was fully developed in Farris (1983) - this article is considered by many as the most important in the field. One of the goals of this article was to reply the assertions of Cartmill (1981), that stated the status of phylogenetic hypotheses are not falsifiable in Popper's sense, arguing that parsimony does not conforms with falsificationism; about this, he wrote that "Phylogenetic reconstruction is possible. However, Popperian phylogenetic reconstruction apparently is not" (Cartmill, 1981, p. 92). One important point advanced by Cartmill is the relation about cladistics, Popper and the evolutionary biology; claiming that they are not compatible in relation to Popper's philosophy. As the reply to Cartmill (1981) goes, Farris (1983) accuses Cartmill's argument to rest on a misrepresentation of Popper. In defense of Popper, Farris connects the ideas on phylogenetic inference to questions regarding the scientific method; Farris, instructs cladists to prefer hypotheses that have greater explanatory power - that is, they require less ad hoc hypotheses. This is so because they reduce the explanatory power of the hypothesis. These arguments became, from then on, the most used for the justification of cladistics (using parsimony). This can be demonstrated by the use of this justification in textbooks of systematic, e.g., Wiley \& Lieberman (2011); Schuh \& Brower (2009); Wheeler (2012). Another application of this approach is found in Kluge $(1997 ; 1998)$ and Nixon \& Carpenter (2011). They argue that explaining congruent synapomorphies as homologies in the more severely tested and less falsified cladogram is considered a consequence of defining homology and that, in this sense, homoplasy can be understood as a quantity of error in the inference of homology, that is, all homoplasy is a mistake. As a matter of clarification, briefly, homoplasy is similarity that is not the result of common ancestry, but of reversion to an ancestral trait in a lineage or independent evolution (convergence or parallelism), i.e., homoplasy is one of the outcomes of evolution. Exploitation of homoplasy can illuminate the limits of phenotypic evolution, nature and the reasons for biases in its direction, and why "descent with modification" can follow predictable paths (Wake et al., 2011). From this, we can see that these systematists "transformed" the theory of evolution in order to fit Popper.

Subsequently, Kluge (2001) argues that homoplasy does not explain anything in the hypothesis process of the relationship between descendant ancestral species. In Kluge (1999) the use of Popper was even stronger, using its testability formula $(S(e, h, b)=C(h, e, b)=(p(e, h$ b) $-\mathrm{p}, \mathrm{b})$ ) / ..., where e is evidence, $\mathrm{h}$ is hypothesis and $\mathrm{b}$ is background knowledge) for systematics. The transformation was done as follows, "therefore, h1 is the most highly corroborated, most severely tested of the three competing cladograms- $C(h 1, e, b)>C(h 2, e, b)$ or $C(h 3, e, b)$, assuming only "descent, with modification." Further, in choosing the least falsified cladogram-according to Farris' phylogenetic parsimony criterion, minimizing requirements for ad hoc propositions of homoplasy-h1 is maximally explanatory, more synapomorphies being interpretable as homologues on $\mathrm{h} 1$ than on $\mathrm{h} 2$ or $\mathrm{h} 3$. (Kluge 1999, p. 433)".

However, as with universal statements, there is a serious problem with this hypothetical-deductive approach and with these ad hoc hypotheses of homoplasy in the systematic. Sober (1988) has argued that Popper's usu- 
al deductive interpretations simply do not apply to the problem of phylogenetic inference. He was the first to argue that one does not deduce the truth of a genealogy of character distributions and process theory, rather, it is inferred that one genealogy is better supported than another (Sober 1988). Later, Rieppel (2005) argued using the methodology of Induction developed by Carnap (1962), more precisely, his requirement of total evidence, demonstrates that phylogenetic systematics is not hypothetic-deductively structured, because this requirement is called while conducting a cladistics analysis. Furthermore, Vogt $(2008,2013)$ has cogently argued that homoplasies are a result of evolution, being part of its background knowledge,thus, not being characterized as ad hoc hypotheses (sensu Farris, 1983). Rieppel (2003, $2004,2005,2006$ ) has also challenged the idea of ad hoc hypotheses of homoplasy in systematics, alongside the failure to apply the Popperian falsifiability to parsimony analysis. Finally, while discussing for abductive reasoning in systematics, Fitzhugh (2006) arrived these same conclusions.

However, again, no systematist from the research group originating during the "systematic wars" gave in to these criticisms. This research group carried out the following process: publications and mutual citations of Popper compliance, failing to take these criticisms into account, or accusing them of not understanding their ideas. Hull (1988) writes that reason, argument, and evidence often decide controversy in science, but when scientists need to make choices, the evidence is never fully determined, nor the arguments fully convincing; and on this he writes that, "mutual positive citations within a research group serve to promote social cohesion within that group. Negative citations of one's opponents also promote cohesion within the group as well as demarcate it from other groups. (Hull, 1988, p. 286)".

To get two concrete examples, let us look at the replies to Rieppel's (2003) work. One of the authors who left to defend their ideas was Kluge (2009). Using words like "...misunderstanding to the use of modus tollens in phylogenetic inference..." Kluge criticized Rieppel's (2003) propositions in using Popper for this, primarily, a way of hiding behind the names of famous philosophers and their isms, thereby often erecting rhetorical arguments with authoritarian content. Farris $(2008$, p. 8$)$ contesting the use of Popper's philosophy by Rieppel (2003), he appealed once more to the Popperian authority by demanding the critics of Popper to "consider the relevant parts of Popper's work."

Again, I can use Hull's (1988) thesis to explain this behavior, since those who oppose others research programs serve to reinforce the internal cohesion of associated research groups, as long as a particular research program is under attack and is at risk of being defeated, proponents of this program tend to present a united cooperative association. This can be explained as one of the reasons for the recipe of the cladists' success. This defense of Popper, among other things, like remaining terminologically rigid and conceptually open (Hull, 1988), that made the cladists win the "systematics war". It is ar- gued here that this was a very relevant factor in keeping themselves socially cohesive, considering that only cladistis had a famous (and professional) philosopher at their methodological disposition and that they would be sure that only cladistics would be pure science (against the pseudosciences of the numerical taxonomists and evolutionary taxonomy). In the case of the numerical taxonomists, they never used Popper in their methodological justifications, but instead used in their philosophy the writings of J.S.L. Gilmour and P.W. Bridgman (Hull, 1981). However, as Hull (1981) argued neither Gilmour nor Bridgman were a professional philosopher, and the combination of phenomenalism and operationalism urged by these two men was long ago rejected as untenable by professional philosophers; they did not had a 'patron saint'. Thus, the numerical taxonomists lost the "systematics wars" because they did not form a sufficiently cohesive group to "survive" this "war." As Hull (1988) argues in the book, "civil war never broke out among the pheneticists, not because pheneticists found themselves in such massive agreement but because their social organization became increasingly diffuse. They did not remain cohesive enough, either socially or conceptually, to speciate. Cladists, to the contrary, remained socially very tightly-knit. As their views became more widely accepted, they fought off attempts to take over their research program from the outside. (Hull, 1988, p. 247)".

"Looking back, it would seem that Sokal made two mistakes. He did not insist strongly enough on conceptual orthodoxy and branched out into too many other areas before his power base in biology was secure. Cladists made neither of these mistakes. Given the power of hindsight, the major mistake that Farris made was to hold on too tightly to the running of the Hennig Society. Conceptual orthodoxy and social cohesion are beneficial, just so long as they are not overdone... (Hull, 1988, p. 275-276)".

\section{CONCLUSION}

As a conclusion, we can see the essential (it was necessary, but not sufficient) influence of Popper for the success and the supremacy of cladistics by winning the "science wars" that led to the demise of numerical taxonomy and evolutionary systematics (Rieppel, 2008b). In the 70's and 80's it was a very important social cohesion factor among the cladists, being used as support against, mainly, the numerical taxonomists, that ended up falling in the ostracism. This is all because Popper's ideas are not appropriate for systematics (this applies to the historical sciences in general). This attitude can be considered not an accurate description of how systematics works, but was, nevertheless, important for the cooperation of this research group, since science, as a social activity, has much of its development from processes that are beyond the evidence and well-supported hypotheses. Scientists in their most difficult times during the conflict of research programs, along with philosophers of science, almost all the time insist that science is primarily a matter of reason, 
argument, and evidence. However, it is very important to take into account the words of Hull "in the ongoing process of science, the inherent worth of ideas is far from irrelevant, but it is also far from sufficient... Being "right" is not enough. Scientists must convert their fellow scientists as well. (Hull, 1988, p. 114)".

\section{ACKNOWLEDGEMENTS}

This essay was part of the discipline "The Social Dimension of Rationality", coordinated by Dr. Caetano Ernesto Plastino. This work was supported by Coordenação de Aperfeiçoamento de Pessoal de Nível Superior - process number 88882.333078/2019-01. Thanks to Leandro de Assis, Rodrigo Dios, Deivys Alvarez and Caetano Ernesto Plastino for valuable comments on earlier versions of this manuscript. Special thanks to Francisco Rômulo (UFRJ) and João Cortese (USP) for encouraging my interests in the Philosophy of Science and Biology.

\section{REFERENCES}

Ax, P. 1987. The phylogenetic system. The systematization of organisms on the basis of their phylogenesis. New York, John Wiley and Sons.

Beatty, J. 1995. The evolutionary contingency thesis. In: Wolters, G. \& Lennox, J.G. (Eds.). Concepts, theories, and rationality in the biological sciences. Pittsburgh, University of Pittsburgh Press. p. 45-81.

Bock, W.J. 1973. Philosophical foundations of classical evolutionary classifications. Systematic Zoology, 22(4): 375-92.

Bradie, M. \& Harms, W. 2017. Evolutionary Epistemology. In: Zalta, E.N. (Ed.). The Stanford Encyclopedia of Philosophy (Spring 2017 ed.). Available at: https://plato.stanford.edu/archives/spr2017/entries/epistemologyevolutionary. Access in: 04/10/2018.

Brower, A.V.Z. 2016. Are we all cladists? In: Williams, D.; Schmitt, M. \& Wheeler, Q. (Eds.). The future of phylogenetic systematics: The legacy of Willi Hennig. Cambridge, Cambridge University Press. p. 88-114.

Carnap, R. 1962. Logical foundations of probability. 2. ed. Chicago, University of Chicago Press.

Cartmill, M. 1981. Hypothesis testing and phylogenetic reconstruction. Zeitschrift für Zoologische Systematik und Evolutionsforschung, 19: 73-96.

Cleland, C.E. 2002. Methodological and epistemic differences between historical science and experimental science. Philosophy of Science, 69: 474-496.

Cracraft, J. 1978. Science, Philosophy, and Systematics. Systematic Zoology, 27: 213-216.

Crother, B.I. \& Murray, C.M. 2015. Testable but not falsifiable? Cladistics, 31: 573-574.

Dupré, J. 1990. Scientific Pluralism and the Plurality of the sciences: comments on David Hull's science as a process. Philosophical Studies, 60: 61-76.

Elgin, M. \& Sober, E. 2017. Popper's Shifting Appraisal of Evolutionary Theory. The Journal of the International Society for the History of Philosophy of Science, 7: 31-55.

Farris, J.S. 1983. The Logical Basis of Phylogenetic Analysis. In: Platnick, N. \& Funk, V.A. (Eds.). Advances in cladistics. New York, Columbia University Press. v. 2, p. 7-36.

Farris, J.S. 2008. Parsimony and explanatory power. Cladistics, 24: 825-847.

Farris, J.S. 2013. Popper: not Bayes or Rieppel. Cladistics, 29: 230-232.
Farris, J.S. \& Platnick, N.I. 1989. Lord of flies: The systematist as study animal. Cladistics, 5: 295-310.

Fitzhugh, K. 2006. The Abduction of Phylogenetic Hypotheses. Zootaxa, 1145: $1-110$.

Gaffney E.S. 1979. An introduction to the logic of phylogeny reconstruction. In: Cracraft, J. \& Eldredge, N. (Eds.). Phylogenetic analysis and paleontology. New York, Columbia University Press. p. 79-111.

Ghiselin, M.T. 1966. On psychologism in the logic of taxonomic controversies. Systematic Zoology, 15: 207-215.

Godfrey-Smith, P. 2007. Popper's philosophy of science: looking ahead. In: Shearmur, J. \& Stokes, G. (Eds.). The Cambridge Companion to Popper. Cambrige University Press. p. 104-124.

Godfrey-Smith, P. 2010. David Hull. Biology and Philosophy, 25(5): 749-53.

Hennig, W. 1950. Grundzuge einer theorie der phylogenetischen systematic. Berlin, Deutscher zentralverlag.

Hennig, W. 1966. Phylogenetic systematics. Urbana, University of Illinois Press.

Hull, D.L. 1970. Contemporary Systematic Philosophies. Annual Review of Ecology and Systematics, 1: 19-54.

Hull, D.L. 1981. The principles of biological classification: The use and abuse of philosophy. PSA Proceedings of the Philosophy of Science Association, v. 2, p. 130-153.

Hull, D.L. 1983. Karl Popper and Plato's metaphor. In: Platnick, N. \& Funk, V.A. (Eds.). Advances in cladistics. New York, Columbia University Press. v. 2, p. 177-89.

Hull, D.L. 1988. Science as a process: an evolutionary account of the social and conceptual development of science. Chicago, University of Chicago Press.

Hull, D.L. 1999. The use and abuse of Sir Karl Popper. Biology \& Philosophy, 14: 481-504.

Kitcher, P. 1988. Selection Among the Systematists. Nature, 336(6196): 277-278.

Kitts. D.B. 1977. Karl Popper, verifiability, and systematic zoology. Systematic Zoology, 26: 185-194.

Kluge, A.G. 1997. Testability and the refutation and corroboration of cladistic hypotheses. Cladistics, 13: 81-96.

Kluge, A.G. 1998. Sophisticated falsification and research cycles: consequences for differential character weighting in phylogenetic systematics. Zoologica Scripta, 26: 349-360.

Kluge, A.G. 1999. The science of phylogenetic systematics: explanation, prediction, and test. Cladistics, 15:429-436.

Kluge, A.G. 2001. Philosophical conjectures and their refutation. Systematic Biology, 50: 322-330.

Kluge, A.G. 2005. What is the Rationale for 'Ockham's Razor' (a.k.a. Parsimony) in Phylogenetic Inference. In: Albert, V.A. (Ed.). Parsimony, phylogeny, and genomics. 0xford: Oxford University Press. p. 15-42.

Kluge, A.G. 2009. Explanation and falsification in phylogenetic inference: Exercises in Popperian philosophy. Acta Biotheoretica, 57: 171-186.

Ladyman, J. 2002. Understanding philosophy of science. London, Routledge.

Losee, J. 2001. A historical introduction to the philosophy of science. 4. ed. New York, Oxford University Press.

Mayr, E. 1965. Numerical Phenetics and Taxonomic Theory. Systematic Zoology, 14: 73-97.

Nelson, G. 1978. Classification and prediction: a reply to ktts. Systematic Zoology, 27: 216-218.

Nixon, K.C. \& Carpenter, J.M., 2011. On homology. Cladistics, 28: 160-169.

Panchen, A.L. 1982. The use of parsimony in testing phylogenetic hypotheses. Zoological Journal of the Linnaen Society, 74: 305-28.

Patterson, C. 1978. Verifiability in systematics. Systematic Zoology, 27: 218-222.

Platnick, N.I. \& Gaffney, E.S. 1977. Systematics: a Popperian perspective. Systematic Zoology, 26: 360-365. 
Platnick, N.I. \& Gaffney, E.S. 1978a. Systematics and the Popperian Paradigm. Systematic Zoology, 27: 381-388.

Platnick, N.I. \& Gaffney, E.S. 1978b. Evolutionary biology: a Popperian perspective. Systematic Zoology, 27: 138-141.

Pompeii AD 79 opens at AMHN april 22. 1979. Grapevine, 36(2): 1-4. Available at: https://archive.org/stream/grapevine3639amer\#page/n9/ mode/2up. Access in: 05/09/2018.

Popper, K.R. 1957. The poverty of historicism. London, Routledge \& Kegan Paul.

Popper, K.R. 1959 [2002]. The logic of scientific discovery. London, Routledge \& Kegan Paul.

Popper, K.R. 1972. Objective knowledge: an evolutionary approach. Oxford, Clarendon Press.

Popper, K.R. 1974. Darwinism as a Metaphysical Research Programme. In: Schilpp, P.A. (Ed.). The Philosophy of Karl Popper. La Salle, IL, Open Court. p. 133-143.

Popper, K.R. 1978. Natural Selection and the emergence of mind. Dialectica, 32(3-4): 339-55.

Rieppel, 0. 2003. Popper and Systematics. Systematic Biology, 52: 259-271.

Rieppel, 0. 2004. What Happens When the Language of Science Threatens to Break Down in Systematics - A Popperian Perspective. In: Williams, D. \& Forey, P. (Eds.). Milestones in Systematics. Boca Raton, CRC Press. p. $57-100$

Rieppel, 0. 2005. The philosophy of total evidence and Its relevance for phylogenetic inference. Papéis Avulsos de Zoologia, 45: 77-89.

Rieppel, 0. 2006. On Concept Formation in Systematics. Cladistics, 22: 474-492.

Rieppel, 0. 2008a. Hypothetico-Deductivism in Systematics: Fact or Fiction? Papéis Avulsos de Zoologia, 48(23), 263-273.
Rieppel, 0. 2008b. Re-writing Popper's philosophy of science for systematics. History and Philosophy of the Life Sciences, 30: 293-316.

Sarkar, S. \& Pfeifer, J. (Eds.). 2006. The philosophy of science: An encyclopedia. London, Routledge.

Schuh, R.T. \& Brower, A.V.Z. 2009. Biological systematics: principles and applications. 2. ed. Ithaca, Cornell University Press.

Sober, E. 1988. Reconstructing the past: parsimony, evolution, and inference. Cambridge, MA, Massachusetts Institute of Technology.

Stamos, D.N. 2007. Popper, laws, and the exclusion of biology from genuine science. Acta Biotheoretica, 55: 357-375.

Sterelny, K. 1994. Science and Selection. Biology and Philosophy, 9: 45-62.

Sterner, B. \& Lidgard, S. 2018. Moving past the systematics wars. Journal of the History of Biology, 51:31-67.

Vogt, L. 2008. The unfalsifiability of cladograms and its consequences. Cladistics, 24: 62-73.

Vogt, L. 2013. Why phylogeneticists should care less about Popper's falsificationism. Cladistics, 30: 1-4.

Wake, D.B.; Wake, M.H. \& Specht C.D. 2011. Homoplasy: from detecting pattern to determining process and mechanism of evolution. Science, 331: 1032-1035.

Wheeler, W.C. 2012. Systematics: A Course of Lectures. Chichester, Wiley-Blackwell.

Wiley, E.0. 1975. Karl R. Popper, systematics, and classification: a reply to Walter Bock and other evolutionary taxonomists. Systematic Zoology, 24: 233-243.

Wiley, E.0. \& Lieberman, B.S. 2011. Phylogenetics: the theory and practice of phylogenetic systematics. 2. ed. Oxford, Wiley.

Williams, D. \& Ebach, M. 2013. Patterson's Curse, Molecular Homology, and the Data Matrix. In: Hamilton, A. (Ed.). The Evolution of phylogenetic systematics. Berkeley, University of California Press. p. 151-188. 